\title{
A Thirteen-year Retrospective Analysis of 179 Odontogenic Tumours in a Nigerian Tertiary Healthcare Facility
}

B Fomete ${ }^{1}$, OD Osunde ${ }^{2}$, JO Ogbeifun ${ }^{3}$

\begin{abstract}
Background: Tumours of odontogenic origin (OTs) resulting from epithelial and mesenchymal elements that are part of the tooth-forming apparatus must be considered as a differential diagnosis when analysing jaw lesions. They may be cystic, myxomatous or sometimes have a mixture of cystic and solid areas.

Objective: To analyse the OTs seen at the Maxillofacial Surgery Department, Ahmadu Bello University Teaching Hospital, Zaria, Nigeria, between 2001 and 2013 based on the World Health Organization's 2005 classification of OTs.

Methods: A retrospective search and analysis was conducted of the medical records of all patients with a histopathologic diagnosis of orofacial tumours and tumour-like lesions seen at the Maxillofacial Surgery Department, Ahmadu Bello University Teaching Hospital, Zaria, Nigeria, from 2001 to 2013.

Results: Odontogenic tumours constituted 179 (15.3\%) cases out of a total of 1170 orofacial tumours and tumour-like lesions seen within the study period. The 179 OTs were found in 101 (56.4\%) males and $78(43.6 \%)$ females, giving a male to female ratio of 1.3:1. The ages of the patients ranged from 12 to 88 years (mean, standard deviation: 33.31, 14.07 years). The lesions were predominantly benign $(n=176 ; 98.3 \%)$, with only three $(1.7 \%)$ being malignant OTs.

Conclusion: The distribution of OTs in this study compared well with that in previous reports from Nigeria.
\end{abstract}

Keywords: Benign, malignant, odontogenic, tumours

\section{Análisis retrospectivo de trece años de 179 tumores odontogénicos en un centro de salud terciaria nigeriana}

B Fomete ${ }^{1}$, OD Osunde 2 , JO Ogbeifun ${ }^{3}$

\begin{abstract}
RESUMEN
Antecedentes: Los tumores de origen odontogénico (TO) como resultado de los elementos epiteliales y mesenquimales que son parte del aparato de formación de los dientes, se deben considerar como diagnosis diferencial a la hora de analizar lesiones maxilares. Pueden ser quísticos, mixomatosos, o constituidas a veces por una mezcla de áreas quísticas y sólidas.
\end{abstract}

From: ${ }^{1}$ Maxillofacial Surgery Department, Ahmadu Bello University Teaching Hospital, Zaria, Nigeria, ${ }^{2}$ Dental and Maxillofacial Department, University of Calabar Teaching Hospital, Calabar, Nigeria and ${ }^{3}$ Dental and Maxillofacial Department, Federal Medical Centre, Makurdi, Nigeria.
Correspondence: Dr B Fomete, Maxillofacial Surgery Department, Ahmadu Bello University Teaching Hospital, Zaria, Nigeria. Email: benfometey@hotmail.com 
Objetivo: Analizar los TO vistos en el Departamento de Cirugía Maxilofacial del Hospital Docente Ahmadu Bello de Zaria, Nigeria, de 2001 a 2013, a partir de la clasificación de TO de la Organización Mundial de la Salud de 2005.

Métodos: Se realizó una búsqueda y análisis retrospectivo de las historias clínicas de todos los pacientes con diagnóstico histopatológico de tumores orofaciales y lesiones tumorales observadas en el Departamento de Cirugía Maxilofacial del Hospital Docente Ahmadu Bello en Zaria, Nigeria, de 2001 a 2013.

Resultados: Los tumores odontogénicos constituyeron 179 casos (15.3\%) de un total de 1170 tumores orofaciales y lesiones tumorales vistas en el periodo de estudio. Los 179 TO fueron encontrados en 101 (56.4\%) varones y 78 (43.6\%) hembras, para un ratio varón-hembra de 1.3:1. Las edades de los pacientes variaron de 12 a 88 años (media, desviación estándar: 33.31, 14.07 años). Las lesiones fueron predominante benignas ( $n=176$; 98.3\%), hallándose solamente tres TO malignos (1.7\%).

Conclusión: La distribución de TO en este estudio es comparable con la de los reportes anteriores en Nigeria.

Palabras clave: Tumores benignos, malignos, odontogénicos

West Indian Med J 2018; 67 (3): 234

\section{INTRODUCTION}

Odontogenic tumours (OTs) are derived from epithelial and mesenchymal elements that are part of the toothforming apparatus $(1,2)$ and must be considered as a differential diagnosis when analysing jaw lesions (3). They may be cystic, myxomatous or sometimes have a mixture of cystic and solid areas. The manadible and maxilla are commonly involved, although soft tissue variants of some OTs have also been reported (4). While the majority of them are benign, a few are malignant and may metastasize outside the jaw (5). Untreated OTs may grow so large causing facial disfigurement and functional impairment of the aero-digestive tract (6).

Globally, OTs have shown geographic variations in their distribution and frequency $(1,3,5)$. Ameloblastomas are the most common OTs reported from Nigeria (4).

There were several individual OT reports from Nigeria, including from the Maxillofacial Surgery Department, Ahmadu Bello University Teaching Hospital, Zaria, Nigeria, but a recent survey of a large series of OTs as a group was lacking $(5,7)$. The purpose of this study was to analyse the OTs seen at the Maxillofacial Surgery Department, Ahmadu Bello University Teaching Hospital, Zaria, Nigeria, between 2001 and 2013 based on the World Health Organization's (WHO) 2005 classification of OTs.

\section{SUBJECTS AND METHODS}

The materials for this study were obtained from a retrospective search of the medical records of all patients with a histopathologic diagnosis of orofacial tumours and tumour-like lesions seen at the Maxillofacial Surgery Department, Ahmadu Bello University Teaching Hospital, from 2001 to 2013. Medical records used included case notes, operation notes, radiographs and radiology reports, histopathology results, and follow-up records. Cases of OTs on the basis of the WHO's 2005 classification (8) were selected for analysis of diagnosis, histopathologic subtyping (for ameloblastomas), age, gender, tumour site(s), clinical features, radiologic appearances, treatment and follow-up records.

\section{RESULTS}

Odontogenic tumours constituted 179 (15.3\%) cases out of a total of 1170 orofacial tumours and tumour-like lesions seen within the study period. The 179 OTs were found in 101 (56.4\%) males and 78 (43.6\%) females, giving a male to female ratio of 1.3:1. The ages of the patients ranged from 12 to 88 years (mean, standard deviation: $33.31,14.07$ years). The lesions were predominantly benign $(\mathrm{n}=176 ; 98.3 \%)$, with only three $(1.7 \%)$ being malignant OTs. Ameloblastoma was the most common OT, accounting for $138(77.1 \%)$ of the tumours, and this was distantly followed by odontogenic 
myxoma $(\mathrm{n}=18 ; 10.1 \%)($ Table 1$)$. Other benign OTs are displayed in Table 1. Five (3.6\%) of the ameloblastomas were of the unicystic type. Peripheral ameloblastoma accounted for six (4.3\%) of the tumours. The rest of the ameloblastomas were intraosseous and of the multicystic type. The observed malignant OTs were ameloblastic carcinoma ( $\mathrm{n}=2 ; 1.1 \%)$ and ameloblastic fibrosarcoma $(\mathrm{n}=1 ; 0.6 \%)$ (Table 1$)$. The gender distribution of the tumours was significant $\left(\mathrm{X}^{2}=15.26, p=0.035\right)$. Ameloblastomas and adenomatoid OTs were observed to occur more in males, with male to female ratios of 1.5:1 and 2.5:1, respectively. In contrast, odontogenic myxoma and odontogenic fibroma were observed more frequently in females than in males, with male to female ratios of 1:2.6 and 1:3, respectively (Table 1).

Table 1: Distribution of odontogenic tumours by gender $(\mathrm{n}=179)$

\begin{tabular}{|c|c|c|c|c|}
\hline Histologic type & Males & Females & Total & $\%$ \\
\hline \multicolumn{5}{|l|}{ Benign } \\
\hline Ameloblastoma & 83 & 55 & 138 & 77.1 \\
\hline Odontogenic myxoma & 5 & 13 & 18 & 10.1 \\
\hline Odontogenic fibroma & 1 & 3 & 4 & 2.2 \\
\hline Adenomatoid odontogenic tumour (OT) & 5 & 2 & 7 & 3.9 \\
\hline Calcifying odontogenic cyst & 0 & 1 & 1 & 0.6 \\
\hline Calcifying epithelial OT & 2 & 0 & 2 & 1.1 \\
\hline Keratocystic OT & 1 & 0 & 1 & 0.6 \\
\hline Odontoma & 1 & 2 & 3 & 1.7 \\
\hline Squamous OT & 1 & 1 & 2 & 1.1 \\
\hline \multicolumn{5}{|l|}{ Malignant } \\
\hline Ameloblastic carcinoma & 2 & 0 & 2 & 1.1 \\
\hline Ameloblastic fibrosarcoma & 0 & 1 & 1 & 0.6 \\
\hline Total & 101 & 78 & 179 & 100 \\
\hline
\end{tabular}

$\mathrm{X}^{2}=15.26, p=0.035$.
Odontogenic tumours occur between the second and fifth decades of life, with a modal age of occurrence of the third decade. For instance, ameloblastoma was seen across a wide age range but with a higher occurrence at the third and fourth decades. Odontogenic myxoma had a similar wide distribution across several age groups but was more frequently seen around the second and third decades (Table 2). The majority of the tumours were found in the mandible ( $\mathrm{n}=163 ; 91.1 \%)$ which was the predominant site for ameloblastoma, odontogenic myxoma, odontogenic fibroma, adenomatoid OT, calcifying epithelial OT and squamous OT (Table 3). The malignant OTs (ameloblastic carcinoma and ameloblastic fibrosarcoma) were limited to the maxilla (Table 3). The site distribution was significant $\left(\mathrm{X}^{2}=107.73, p=\right.$ 0.001 ). The duration of the symptoms ranged from seven months to 25 years. Jaw swellings and displacement of the associated teeth were the most common presentations (Table 4). The other presentations were toothache, pain and ulceration.

\section{DISCUSSION}

The prevalence of OTs in the present study was about $15.3 \%$ of a total of 1170 orofacial tumours and tumourlike lesions. While this is higher than the $9.6 \%$ reported from Lagos (9), it is much lower than the $41.0 \%$ reported by Lawal et al (4), from Ibadan, and also lower than the $32 \%$ earlier reported by Adebayo et al (8) from Kaduna, Nigeria, from where the present study was also conducted. The maxillofacial unit in Kaduna was the only treatment centre in northern Nigeria for a number of years and so the unit received referrals from the whole of

Table 2: Distribution of odontogenic tumours by age group $(n=179)$

\begin{tabular}{|c|c|c|c|c|c|c|c|c|}
\hline Histologic type & $\begin{array}{l}11-20 \\
\text { years }\end{array}$ & $\begin{array}{l}21-30 \\
\text { years }\end{array}$ & $\begin{array}{l}31-40 \\
\text { years }\end{array}$ & $\begin{array}{l}41-50 \\
\text { years }\end{array}$ & $\begin{array}{l}51-60 \\
\text { years }\end{array}$ & $\begin{array}{l}61-70 \\
\text { years }\end{array}$ & $\begin{array}{l}\text { Over } 70 \\
\text { years }\end{array}$ & Total \\
\hline \multicolumn{9}{|l|}{ Benign } \\
\hline Ameloblastoma & 25 & 43 & 32 & 20 & 15 & 2 & 1 & 138 \\
\hline Odontogenic myxoma & 8 & 5 & 1 & 2 & 1 & 0 & 1 & 18 \\
\hline Odontogenic fibroma & 1 & 1 & 2 & 0 & 0 & 0 & 0 & 4 \\
\hline Adenomatoid odontogenic tumour (OT) & 3 & 2 & 2 & 0 & 0 & 0 & 0 & 7 \\
\hline Calcifying odontogenic cyst & 0 & 0 & 0 & 1 & 0 & 0 & 0 & 1 \\
\hline Calcifying epithelial OT & 0 & 0 & 1 & 1 & 0 & 0 & 0 & 2 \\
\hline Keratocystic OT & 0 & 0 & 1 & 0 & 0 & 0 & 0 & 1 \\
\hline Odontoma & 0 & 2 & 1 & 0 & 0 & 0 & 0 & 3 \\
\hline Squamous OT & 0 & 0 & 0 & 1 & 0 & 0 & 1 & 2 \\
\hline \multicolumn{9}{|l|}{ Malignant } \\
\hline Ameloblastic carcinoma & 0 & 0 & 1 & 1 & 0 & 0 & 0 & 2 \\
\hline Ameloblastic fibrosarcoma & 1 & 0 & 0 & 0 & 0 & 0 & 0 & 1 \\
\hline Total & 38 & 53 & 41 & 26 & 16 & 2 & 3 & 179 \\
\hline
\end{tabular}

$\mathrm{X}^{2}=50.42, p=0.806$. 
Table 3: Site distribution of 179 odontogenic tumours

\begin{tabular}{lllllll}
\hline Histologic type & Mandible & Maxilla & $\begin{array}{l}\text { Mandible/ } \\
\text { Maxilla }\end{array}$ & Temporal & Parotid & Total \\
\hline Benign & & & & & \\
Ameloblastoma & 130 & 5 & 0 & 1 & 2 & 138 \\
Odontogenic myxoma & 17 & 1 & 0 & 0 & 0 & 18 \\
Odontogenic fibroma & 3 & 0 & 1 & 0 & 0 & 4 \\
Adenomatoid odontogenic tumour (OT) & 6 & 1 & 0 & 0 & 0 & 7 \\
Calcifying odontogenic cyst & 1 & 0 & 0 & 0 & 0 & 1 \\
Calcifying epithelial OT & 2 & 0 & 0 & 0 & 0 & 2 \\
Keratocystic OT & 1 & 0 & 0 & 0 & 0 & 1 \\
Odontoma & 1 & 2 & 0 & 0 & 0 & 3 \\
Squamous OT & 2 & 0 & 0 & 0 & 0 & 2 \\
Malignant & & & & & & \\
Ameloblastic carcinoma & 0 & 2 & 0 & 0 & 0 & 2 \\
Ameloblastic fibrosarcoma & 0 & 1 & 0 & 0 & 0 & 1 \\
Total & $\mathbf{1 6 3}$ & $\mathbf{1 2}$ & $\mathbf{1}$ & $\mathbf{1}$ & $\mathbf{2}$ & $\mathbf{1 7 9}$ \\
\hline X & & & & & & \\
\hline
\end{tabular}

$\mathrm{X}^{2}=107.73, p=0.001$.

Table 4: $\quad$ Main clinical features in odontogenic tumours $(n=179)$

\begin{tabular}{llllll}
\hline Tumour type* & Swelling & Pain & Toothache & Displaced tooth & Ulceration \\
\hline Ameloblastoma & 138 & 5 & 58 & 128 & 0 \\
Odontogenic myxoma & 18 & 0 & 16 & 15 & 0 \\
Odontogenic fibroma & 4 & 0 & 1 & 0 & 0 \\
Adenomatoid odontogenic tumour (OT) & 7 & 0 & 3 & 4 & 1 \\
Calcifying odontogenic cyst & 1 & 0 & 0 & 0 & 0 \\
Calcifying epithelial OT & 2 & 0 & 0 & 0 & 0 \\
Keratocystic OT & 1 & 0 & 0 & 1 & 0 \\
Odontoma & 1 & 0 & 0 & 0 & 0 \\
Squamous OT & 2 & 0 & 0 & 0 & 0 \\
Ameloblastic carcinoma & 2 & 2 & 1 & 1 & 2 \\
Ameloblastic fibrosarcoma & 1 & 1 & 1 & 1 & 1 \\
\hline
\end{tabular}

* Each tumour type displayed more than one clinical feature.

northern Nigeria as well as some states in the north central part of the country. With the establishment of more maxillofacial treatment centres in some of the adjoining states, most of the patients prefer to seek treatment at places that are closer to them for obvious logistic reasons. This probably accounted for the much reduced prevalence of OTs observed in the present study. The prevalence of OTs is generally believed to be low in some places $(10,11)$. In a recent Brazilian study, OTs constituted only $3 \%$ out of 11181 oral and maxillofacial cases examined (12). The higher mandibular occurrence, wide age distribution with a peak at third decade, and the male to female ratio of 1.3:1 observed for OTs in this study agreed with the reports of previous authors $(4,5$, $8,9)$.

The very high frequency of occurrence for benign OTs was again reaffirmed by the results of this study where benign tumours constituted about $98.3 \%$ of all the OTs observed in this series. Ameloblastoma, a benign but locally aggressive slow-growing OT (7), was the most frequently observed tumour, and this is consistent with earlier reports from Nigeria and other parts of Africa and Asia $(2,8,13)$. This contrasts with reports from the Western world that found odontomas as the most frequently observed OT $(10,11,14)$. The relatively high frequency of ameloblastomas in the present study compared to European and American studies may be explained in terms of racial and geographical distribution and regional differences in clinical practice. Because of their rather less aggressive radiological appearance and asymptomatic clinical nature, odontomas are not routinely treated in Nigerians and, even if treated, are often not sent for histology by some practitioners. Other reasons adduced for the relatively high frequency of occurrence 
are the heterogeneous epithelial origin of ameloblastoma $(15,16)$ and the 'harvesting phenomenon' as defined by Anand et al (17). As with other published reports, ameloblastoma had a strong predilection for the mandible, a slight male predominance, and a peak age of occurrence at the third and fourth decades $(7-9,18)$.

Other OTs observed in this series were odontogenic myxomas, which were the next most common OT after ameloblastomas, adenomamatoid OTs and odontogenic fibromas. Although the result of the present study is in tandem with that of Ladeinde et al (9), with regard to the frequency distribution of OTs, it differs from other Nigerian studies that found adenomatoid OTs as the second most common OT $(19,20)$. In the present study, only one $(0.6 \%)$ case of keratocystic OT (KCOT) was observed. The true frequency of KCOTs among Nigerians is difficult to ascertain, and comparison with previous studies may be difficult. This is because most of the published works on OTs among Nigerians were carried out based on the older WHO classification of OTs where KCOTs were categorized under cyst. The prevalence of KCOTs in recent studies from Nigeria was about $8 \%(4,6)$. In a review of 156 OTs, based on the WHO's 2005 classification, from Calabar, Nigeria, Anyanechi and Saheeb did not record any case of KCOT (20). Whether this was a deliberate omission, to make for easy comparison with previous studies as opined by Guerrisi et al (21), is not clear. In other parts of the world, KCOTs are reported as the most common OT in studies that used the WHO's 2005 classification $(12,22)$.

In support of the several published studies, malignant OTs are very rare $(6,9,13,19)$ and accounted for only $1.7 \%$ of all the OTs in this series. Ameloblastic carcinoma is the most common malignant OT. The only two cases observed in the present study which were seen only in males in the fourth and fifth decades of life were confined to the maxilla. Due to the very small number of cases observed in this series, comparison with previous studies may be misleading.

\section{CONCLUSION}

The distribution of OTs in this study compared well with that in previous reports from Nigeria. In contrast to some other global studies, the inclusion of KCOTs as OTs did not influence the overall prevalence of this group of heterogeneous tumours in the present study.

\section{REFERENCES}

1. Butt FMA, Ogengo J, Bahra J, Chindia ML, Dimba EAO, Wagaiy E. A 19-year audit of benign jaw tumours and tumour-like lesions in a teaching hospital in Nairobi, Kenya. Open J Stomatol 2012; 2: 54-9.

2. Taghavi N, Rajabi M, Mehrdad L, Sajjadi S. A 10-year retrospective study on odontogenic tumors in Iran. Indian J Dent Res 2013; 24: 220-4.

3. Santos JN, Pereira PL, de Figueredo CRLV, de Souza LB. Odontogenic tumors: analysis of 127 cases. Pesqui Odontol Bras 2001; 15: 308-13.

4. Lawal AO, Adisa AO, Olusanya AA. Odontogenic tumours: a review of 266 cases. J Clin Exp Dent 2013; 5: e13-7.

5. Arotiba JT, Ajike SO, Akadiri OA, Fasola AO, Akinmoladun VI, Adebayo ET et al. Odontogenic tumours: analysis of 546 cases from Nigeria. J Maxillofac Oral Surg 2007; 6: 44-50.

6. Bassey GO, Osunde OD, Anyanechie CE. Maxillofacial tumors and tumor like lesions in a Nigerian teaching hospital: an eleven year retrospective analysis. Afri Health Scien 2014; 14: 56-63.

7. Fomete B, Adebayo ET, Ogbeifun JO. Ameloblastoma: our clinical experience with 68 cases. J Orofac Sci 2014; 6: 17-24.

8. Adebayo ET, Ajike SO, Adekeye EO. A review of 318 odontogenic tumors in Kaduna, Nigeria. J Oral Maxillofac Surg 2005; 63: 811-9.

9. Ladeinde AL, Ajayi OF, Ogunlewe MO, Adeyemo WL, Arotiba GT, Bamgbose BO et al. Odontogenic tumors: a review of 319 cases in a Nigerian teaching hospital. Oral Surg Oral Med Oral Pathol Oral Radiol and Endo 2005; 99: 191-5.

10. Bhaskar SN. Oral tumors of infancy and childhood. J Pediatr 1963; 63: 195-210.

11. Tay ABG. A 5 year survey of oral biopsies in an oral surgical unit in Singapore: 1993-1997. Ann Acad Med Singapore 1999; 28: 665-71.

12. Servato JP, Prieto-Oliveira P, de Faria PR, Loyola AM, Cardoso SV. Odontogenic tumours: 240 cases diagnosed over 31 years at a Brazilian university and a review of international literature. Int J Oral Maxillofac Surg 2013; 42: 288-93.

13. Kamulegeya A, Kalyanyama BM. Oral maxillofacial neoplasms in an East African population: a 10 year retrospective study of 1863 cases using histopathological reports. BMC Oral Health 2008; 8: 19.

14. Jones AV, Franklin CD. An analysis of oral and maxillofacial pathology found in adults over a 30-year period. J Oral Pathol Med 2006; 35: 392-401.

15. Shafer WG, Hine MK, Levy BM, Tomich CE. Ectodermal tumors of odontogenic origin. A meloblastoma. A textbook of oral pathology. Philadelphia: JB Saunders 1983; 276-92.

16. Tajima Y, Yokose S, Sakamoto E, Yamatoto Y, Utsumi N. Ameloblastoma arising in calcifying odontogenic cyst. Report of a case. Oral Surg Oral Med Oral Pathol 1992; 74: 776-9.

17. Anand SV, Davy W, Cohen B. Tumors of the jaws in West Africa: a review of 256 patients. Br Surg 1967; 54: 910-7.

18. Chidzonga MM, Lopez VM, Alverez AP. Odontogenic tumours: analysis of 148 cases in Zimbabwe. Cen Afr J Med 1996; 42: 158-61.

19. Ajayi OF, Ladeinde AL, Adeyemo WL, Ogunlewe MO. Odontogenic tumors in Nigerian children and adolescents - a retrospective study of 92 cases. World J Surg Oncol 2004; 2: 39.

20. Anyanechi CE, Saheeb BD. A review of 156 odontogenic tumours in Calabar, Nigeria. Ghana Med J 2014; 48: 163-7.

21. Guerrisi M, Julia Piloni M, Keszler A. Odontogenic tumors in children and adolescents: a 15-year retrospective study in Argentina. Med Oral Patol Oral Cir Bucal 2007; 12: E180-5.

22. Tawfik MA, Zyadia MM. Odontogenic tumors in Dakahlia, Egypt: analysis of 82 cases. Oral Surg Oral Med Oral Pathol Oral Radiol Endod 2010; 109: 67-73. 